\title{
sciendo
}

Folia Oeconomica Stetinensia

Volume 20 (2020) Issue 2

DOI: $10.2478 /$ foli-2020-0046
WYDZIAL NAUK EKONOMICZNYCH I ZARZA_DZANIA

\section{SOUTH AFRICAN UNEMPLOYMENT IN THE POST-FINANCIAL CRISIS ERA: WHAT ARE THE DETERMINANTS?}

\author{
Lutho Mbekeni, MCom ${ }^{1}$ \\ Andrew Phiri, Ph.D. ${ }^{2}$ \\ Nelson Mandela University \\ Faculty of Business and Economic Sciences \\ Department of Economics \\ University Way \\ Summerstrand, Port Elizabeth, 6019, South Africa \\ 1e-mail:215217519@mandela.ac.za \\ ORCID: 0000-0002-6228-5000 \\ ${ }^{2}$ e-mail: andrew.phiri@mandela.ac.za \\ ORCID: 0000-0003-1775-3546
}

Received 12 September 2019, Accepted 3 October 2020

\begin{abstract}
Research background: High unemployment rates are one of the greatest economic challenges facing the post-apartheid South African government over the past two decades and this problem has become more worrisome in the post-global financial crisis period.

Purpose: Our study examines the determinants of unemployment for the South African economy in the post-crisis period over a quarterly frequency period of 2009:Q1 to 2018:Q4. The determinants are examined for four classes of unemployment rates (total, male, female and youth) and we further partition possible unemployment determinants into fiscal, monetary and macroeconomic variables.

Research methodology: We employ the autoregressive distributive lag (ARDL) models.

Results: We find income tax, repo rates, economic growth, trade, investment, household debt and savings to be significant determinants of unemployment in the post-crisis South African economy and yet we note discrepancies of the significance of these determinants amongst different unemployment categories.

Novelty: No study has examined the determinants of unemployment in South Africa in the post-financial crisis era.
\end{abstract}

Keywords: unemployment, ARDL, financial crisis, South Africa

JEL classification: C13, C32, C52, E24 


\section{Introduction}

South Africa, being arguably the leading nation in Africa in terms of economic development, as reflected in its advanced infrastructure, financially developed sector and relatively sound fiscal stance, surprisingly suffers from one of the highest unemployment rates worldwide. In overcoming the brutal legacy of an Apartheid regime in the 1990's whereby African citizens were socially marginalized, the post-Apartheid government has since dedicated itself towards devising policies aimed at tackling unemployment and poverty. For instance, the earlier Reconstruction and Development Plan (RDP) of 1994; the Growth, Employment and Redistribution (GEAR) programme of 1996 as well as the Accelerated and Shared Growth Initiative of South Africa (ASGISA) of 2005 all set numerical targets of attaining higher fiscal and macroeconomic prosperity as a means of addressing high unemployment levels in the country. Moreover, unemployment-specific policies such as the targeted Wage Subsidy as well as the Immigration reform policy were further introduced to directly address the problem of high unemployment amongst as caused by labour market imperfections. Nevertheless, historical unemployment measurements as reported by Statistics South Africa (STATSSA) reflect the unsuccessful results of these policies in addressing the unemployment problem seeing that the unemployment rate has escalated from 19 percent in 1994 to 28 percent in 2018.

In an earlier study, Kingdon and Knight (2007) noted that two factors have mainly accounted for the observed increased unemployment rate in the post-Apartheid period. Firstly, the authors ascertain that increase in the women labour participation rate which increased from $38.3 \%$ (in 1995) to $47.8 \%$ (in 2003) compared to the labour force participation rate increase in men from 58.6 to $61.2 \%$, experienced during the same period. Secondly, the authors further acknowledge that the experienced increase in the unemployment rate occurred due to economic growth being insufficient for job creation and hence unable to match the growth in the labour force that occurred during this period. This is evident by the growth in total employment, which grew by 2 million new jobs between 1995 and 2003, was much less than the growth in the labour force, which grew by 6.3 million new entries to the labour market over the same time period. In a more recent study, du Toit, De Witte, Rothman and Van den Broeck (2018) attribute the high rate of unemployment in South Africa to socio-political issues such as lack of tertiary education, lack of proper skills training, heavy regulations that affect foreign direct investments (FDI) inflows as well as slow economic growth. Moreover, Patel and Choga (2018), note that unemployment may be caused by fiscal variables such as government expenditure or by financial variables such as the Central Bank's repurchase (repo) rate. 
According to the International Labour Organization (ILO, 2018) South Africa's unemployment rate worsened in the post-financial crisis period, recording an unemployment rate of $27.3 \%$ worsened in the post-in 2017 , and youth unemployment rate of $53.62 \%$. Notably, these statistics are more than double (and even triple!) that of fellow BRICS associates (China (3.9\% in 2017), Brazil (13.1\% in 2017), India (6.9\% in 2017), and Russia (6.0\% in 2017)). Our research is concerned with identifying fiscal, monetary and macroeconomic determinants of unemployment for the South African economy for the post-global financial crisis period of 2007 to 2018. Our study focuses on the post-crisis period since it represents a new era of policy design, with the NGP and NDP recently introduced as public policy guidelines in coordinating fiscal, monetary and macroeconomic objectives in addressing problems relating to unemployment and poverty. Notably, previous South African literature (Naude, SerumagaZake, 2001; Kingdon, Knight, 2007; Kyei, Gyekye, 2012; Dagume, Gyekye, 2016; du Toit et al., 2018) has not exclusively investigated possible unemployment determinants for the postcrisis era hence ignoring important structural breaks existing over long periods of data. Our study addresses this empirical hiatus. Nevertheless, in doing so we are restricted into selecting time series data available in quarterly frequency to ensure that we obtain enough observations for a cointegration analysis. To further ensure the rigidity of our analysis, we further disseminate our data into four classes corresponding to total, male, female and youth unemployment rates. In carrying out our empirical analysis, we depend on the autoregressive distributive lag (ARDL) cointegration model of Pesaran, Shin and Smith (2001) which presents methodological advantages such as catering for small sample sizes as well as being applicable with a time series with differing orders of integration.

The rest of our study is organized as follows. The next section of the paper presents the literature review. The third section of the paper outlines the empirical framework of the study whereas the empirical findings are presented in section four of the paper. Section five concludes our study.

\section{Fiscal, monetary and macroeconomic determinants of unemployment as dictated by literature}

The first order of complexity in selecting determinants of unemployment stems from the fact that there exists no single encompassing theory of unemployment and instead one is obligated to review a handful of independent theories linking different economic variables to unemployment. One of the oldest theories linking unemployment with economic activity 
is Okun's (1962) law, which assumes a negative relationship between unemployment and economic output. Notably this relationship has received much empirical support in industrialized economies such as the United States (Grant, 2018; Guisinger, Hernandez-Murillo, Owyang, Sinclair, 2018), Spain (Porras-Arena, Martin-Roman, 2019), OECD countries (de Mendonca, de Oliveira, 2019) and yet has received very little empirical support for the South African economy (see Moroke, Leballo, Mello, 2014; Banda, Ngirande, Hogwe, 2016). Another popular theory describing the dynamics of unemployment across the steady-state comes courtesy of the Phillips curve which assumes an inverse relationship between inflation and unemployment. Yet again, whereas the Phillips curve received empirical support in the earlier studies of Gordon (1990) and Fuhrer (1995), the traditional Phillips curve has been found wanting for the South African economy (Fedderke and Schaling (2005) and Burger and Marnikov (2006) and Phiri (2016)).

Beyond the Phillips curve, the monetary transmission mechanism depicted in Mishkin (1995) and Ireland (2005), outlines the pass-through effect from both the Central Bank's policy instrument and the exchange rate through to the real variables such as unemployment. In a nutshell, this transmission assumes a positive relationship between interest rates and unemployment (i.e. expansionary policy lowers unemployment whilst contractionary policy increases unemployment). Along the same mechanism, an appreciation (depreciation) of currency lowers (increases) unemployment via an improved (deteriorated) current account balance. Closely related with this later transmission, is the possibility of an inverse relationship between trade and unemployment. Dutt, Mitra and Ranjan (2009) developed a formal model of trade and search-induced unemployment, where trade results from Heckscher-Ohlin $(\mathrm{H}-\mathrm{O})$ and Ricardian comparative advantage results in negative trade-unemployment relationship more especially for labour intensive economies. Empirical evidence presented by Egger and Kreickemeier (2009) as well as Felbermayr, Schmerer and Prat (2011) demonstrate that higher trade openness is associated with a lower structural unemployment whereas Hasan, Mitra, Ranjan and Ahsan (2012) find no evidence of any unemployment reduction effects caused by increased trade activity.

On the real economy side of the monetary transmission mechanism, are the investment and savings variables, which are both a consequence of consumption decisions and these variables directly transmitted into other real macroeconomic variables like unemployment. We note a significant number of academic studies which depict domestic investments as being a crucial determinant of unemployment over the steady-state. For instance, Malley and Moutos (2001) find that for OECD countries, an increase in the domestic capital stock relative to the foreign capital stock allows domestic firms to compete more effectively and to capture market shares 
at the expense of increased unemployment in foreign countries and decreased unemployment in domestic countries. On the other hand, Driver and Munoz-Bugarin (2010) present a wage bargaining theoretical model in which the labour share increases with improved capital accumulation over the steady state. More recently Guerrazzi (2015) developed a DSGE model with a search framework in which households decide about consumption while firms consider recruiting efforts and investment decisions and find that lower (higher) investment and lower (higher) consumption pushes unemployment upwards (downwards).

Using a vector autoregressive (VAR) framework, Bande-Ramudo, Fernandez-Grela and Riveiro-Garcia (2014) found that permanent shifts in the consumption-savings patterns exert permanent effect on investment and consequentially this spillovers to the unemployment rate, with the savings-unemployment relationship being established to being positive. This evidence is contrary to the earlier findings of Latif (1996), who observe that increased savings is not significantly related with unemployment over the steady-state. Another important macroeconomic determinant of unemployment found in the literature is household debt, with a handful of authors exploring how household debt interacts with the labour market via aggregate demand. Turinetti and Zhuang (2011) find that for the US economy, unemployment is reduced with higher household debt. Similarly, Bethune, Rocheteau and Rupert (2015) as well as Shaffer and Zuniga (2016) established a negative household debt-unemployment relationship for the US economy and further assert that unemployment is more responsive to household debt than to interest rates.

The theoretical framework for the relationship between unemployment and fiscal variables is not as concrete as those for monetary and other macroeconomic variables. However, there are a handful of studies which establish an empirical relationship between unemployment and fiscal variables although the overall evidence can be best described as inconclusive. For instance, Planas, Roeger and Rossi (2007) as well as Berger and Everaert (2010) found that labour taxes have a positive effect on unemployment in the EU and OECD countries, respectively. On the other hand, Blanchard and Wolfers (2000) found that the estimated elasticity of unemployment to labour taxes is zero for European countries. Concerning fiscal spending, Feldman (2006) and Linnemann (2010) found that government size is most likely to increase unemployment because i) it crowds out private investment ii) a large government size is accompanied by a small private sector and hence undermines the ability of the private sector to absorb potential labour into the workforce iii) high government expenditure requires high taxes, which in turn, reduces the disposable income of private households and hence aggregate demand. Conversely, Abrams (1999) and Mahdavi and Alanis (2013) found that increased government spending 
does not assist in reducing unemployment and highlight that a large government sector is more likely to increase unemployment particularly for female and low skilled labourers. In separate studies, Simeon and Alexandrakis (2015) and Dias (2017) show that high government debt levels as opposed to government spending in the Eurozone area have been the underlying cause of unemployment in the Euro area for periods subsequent to the Sovereign debt crisis of 2010.

In tying together the observed theoretical and empirical intuition gathered from the review of the associated literature, we find it best to categorize the possible determinants of unemployment into three broad categories. Firstly, there are the monetary determinants of unemployment which are inclusive of interest rates, exchange rates and the inflation rate. Secondly there are the fiscal determinants of unemployment which are inclusive of government expenditure, income taxation and government debt. Thirdly, there are other macroeconomic determinants of unemployment which include economic growth, trade, savings rate, domestic investment and household debt. In the following section of the paper we outline the empirical framework used to investigate these possible determinants for the South African economy.

\section{Analytical framework}

Having reviewed the literature for possible fiscal, monetary and macroeconomic determinants of unemployment, we empirically model three regression functions encompassing the possible determinants of unemployment. The first regression function models the fiscal determinants of unemployment:

$$
U=f(D E B T, T A X, E X P)
$$

where $U$ is the unemployment rate, $D E B T$ is government debt, TAX is income taxation and EXP is government expenditure. The second regression function models the monetary determinants of unemployment:

$$
U=f(R E P O, I N F, E X C)
$$

where $R E P O$ is the repurchase rate, INF is the inflation rate and $E X C$ are the exchange rate. The third regression function models the macroeconomic determinants of unemployment:

$$
U=f(G D P, T R A D E, I N V, H H D E B T, S A V)
$$

where GDP is output growth, TRADE is trade openness, INV is domestic investment, HHDEBT is household debt and $S A V$ is savings. We rely on the $A R D L$ bounds cointegration approach 
of Pesaran et al. (2001) to estimate regressions (1) to (3). Re-specifying equations (1) to (3) in compact $A R D L$ format results in the following estimation regressions:

$$
\Delta U_{t}=\beta_{0}+\beta_{0} U_{t-i}+\beta_{0} X_{t-i}+\sum_{i=1}^{n} \beta_{2} \Delta U_{t-i}+\sum_{i=1}^{n} \quad \beta_{2} \Delta X_{t-+i}+\varepsilon_{t}
$$

where $X_{t}$ is the vector of unemployment determinants, $\beta_{0}$ is the constant, $\Delta$ is the first difference operator, $\beta_{i}$ 's are the regression coefficients, $\mathrm{t}$ is time period, $\mathrm{n}$ is number of lags, and $\varepsilon_{t}$ is a normally distributed disturbance term. To test for cointegration effects in regressions (4) to (6), Pesaran et al. (2001) propose testing the following joint null hypothesis of no cointegration, i.e. $\mathrm{H}_{0}: \beta_{1}=\beta_{2}=\ldots=\beta_{i}=0$, against the alternative hypothesis of significant cointegration effects, i.e. $\mathrm{H}_{1}: \beta_{1} \neq \beta_{2} \neq \ldots \neq \beta_{i} \neq 0$. The estimated $F$-statistic value is then compared against the critical values drawn by Pesaran et al. (2001) and $A R D L$ cointegration effects are only validated if the computed F-statistic value lies above the upper critical bound values. This would imply that there is one cointegration vector amongst the time series. In the presence of significant cointegration effects, the following associated unconditional error correction models (UECM) regressions can be estimated:

$$
\Delta U_{t}=\beta_{0}+\psi E C T_{t-1}+\sum_{i=1}^{n} \beta_{1} \Delta U_{t-i}+\sum_{i=1}^{n} \beta_{2} \Delta X_{t-i}+\varepsilon_{t}
$$

where $E C T_{t-1}$ is the error correction term, which measures the speed of the adjustment back to steady-state equilibrium after external shocks in the economy, and $\psi$ is the coefficient of the error correction term.

\section{Analytical framework}

\subsection{Data description and integration properties}

As mentioned before, our study examines the determinants of unemployment in South Africa for the post-crisis period. Due to this constraint, it is important that we obtain quarterly time series data from various sources to ensure enough observations for an empirical analysis. The quarterly data employed in the study has all been obtained from the Federal Reserve Economic Data (FRED) and the South African Reserve Bank (SARB) online databases. From the FRED database we collected our unemployment series for four categories of unemployment, namely total unemployment rate aged 15 and over for all persons $\left(\mathrm{U}_{\mathrm{TOTAL}}\right)$, total unemployment rate aged 15 and over for all males $\left(\mathrm{U}_{\mathrm{MALE}}\right)$, total unemployment rate aged 15 and over for all females $\left(\mathrm{U}_{\text {FEMALE }}\right)$ and total unemployment rate aged 15 to 24 for all persons $\left(\mathrm{U}_{\text {YOUTH }}\right)$. On the 
other hand, the remaining time series variables have been collected from the SARB database and include i) national government debt as a percent of GDP (DEBT), ii) total government expenditure as a percent of GDP (EXP), iii) taxes on income, profit and capital gains as a percentage of total revenue (TAX), iv) CPI inflation (INF), v) the repurchase rate (REPO), vi) the US/ZAR exchange rate (EXC), vii) economic growth (GDP), viii) Household debt to the disposable income of households (HHDEBT) ix) Ratio of gross savings to GDP (SAV) $\mathrm{x}$ ) Exports of goods and services (TRADE) xi) Ratio of gross fixed capital formation to GDP (INV). Our data has been collected over a uniform quarterly period of 2008:Q1 to 2018:Q4and priori to our empirical analysis, we performed ADF, PP and DF-GLS test on the first differences of the variables in order to ensure that none of the time series is integrated of order I(2) or higher. The unit root test results on the first differences of the series as reported in Table 1 confirms that none of our time series data is integrated of $\mathrm{I}(2)$ or higher, thus fulfilling the requirement to implement the ARDL methodology.

Table 1. Unit root test results (First differences)

\begin{tabular}{|c|c|c|c|c|c|c|}
\hline & \multicolumn{2}{|c|}{$\mathrm{ADF}$} & \multicolumn{2}{|c|}{ PP } & \multicolumn{2}{|c|}{ DF-GLS } \\
\hline & drift & drift and trend & drift & drift and trend & drift & drift and trend \\
\hline $\mathrm{U}_{\text {TOTAL }}$ & $-8.705 * * *$ & $-8.620 * *$ & $-8.705 * * *$ & $-8.606 * * *$ & $-7.250 * * *$ & $-8.158 * * *$ \\
\hline $\mathrm{U}_{\text {FEMALES }}$ & $-10.553 * * *$ & $-10.436 * * *$ & $-10.358 * * *$ & $-10.234 * * *$ & $-10.098 * * *$ & $-10.614 * * *$ \\
\hline $\mathrm{U}_{\text {MALES }}$ & $-7.606^{* * *}$ & $-7.626 * * *$ & $-7.580 * * *$ & $-7.626 * * *$ & $-5.971 * * *$ & $-6.807 * * *$ \\
\hline $\mathrm{U}_{\text {YOUTH }}$ & $-7.512 * * *$ & $-7.615^{* * *}$ & $-7.725 * * *$ & $-8.422 * * *$ & $-6.136^{* * *}$ & $-7.193^{* * *}$ \\
\hline DEBT & $-3.984 * * *$ & $-4.328 * * *$ & $-11.480 * * *$ & $-11.225 * * *$ & -0.852 & $-2.943 *$ \\
\hline TAX & $-7.758 * * *$ & $-7.694 * * *$ & $-7.732 * * *$ & $-7.677 * * *$ & $-7.713^{* * *}$ & $-7.840^{* * *}$ \\
\hline EXP & $-14.030 * * *$ & $-13.870 * * *$ & $-14.944 * * *$ & $-14.718 * * *$ & $-2.630 * * *$ & $-11.872 * * *$ \\
\hline INF & $-8.593 * * *$ & $-8.536^{* * *}$ & $-13.065 * * *$ & $-14.113 * * *$ & $-8.028 * * *$ & $-9.121 * * *$ \\
\hline $\mathrm{EXC}$ & $-7.443 * * *$ & $-7.350 * * *$ & $-20.600 * * *$ & $-24.253 * * *$ & $-8.072 * * *$ & $-8.598 * * *$ \\
\hline REPO & $-3.356^{* *}$ & $-4.086 * *$ & $-3.567 * *$ & $-3.965 * *$ & $-2.719 * *$ & $-3.538 * *$ \\
\hline GDP & $-5.834 * * *$ & $-5.914 * * *$ & $-19.120 * * *$ & $19.949 * * *$ & $-6.127 * * *$ & $-7.770^{* * *}$ \\
\hline TRADE & $-5.542 * * *$ & $-5.653 * * *$ & $-16.603 * * *$ & $-15.231 * * *$ & 0.259 & $-7.246^{* * *}$ \\
\hline INV & $-4.863 * * *$ & $-4.782 * * *$ & $-4.800 * * *$ & $-4.702 * * *$ & $-2.406^{* *}$ & $-4.025 * * *$ \\
\hline HHDEBT & $-5.855^{* * *}$ & $-5.834 * * *$ & $-5.849 * * *$ & $-5.822 * * *$ & $-2.761^{* * *}$ & $-3.734 * *$ \\
\hline SAV & $-7.963 * * *$ & $-7.854 * * *$ & $-9.102 * * *$ & $-8.924 * * *$ & $-7.345 * * *$ & $-7.925 * * *$ \\
\hline
\end{tabular}

Notes: $* * *, * * *$ denote the $1 \%, 5 \%$ and $10 \%$ significance levels respectively.

Source: ..?? 


\subsection{Fiscal variables as determinants of unemployment}

We begin our empirical analysis by examining the fiscal determinants of unemployment for our four classes of unemployment namely, total, male, female and youth categories. Three main findings are drawn from the empirical results reported in Table 2. Firstly, government debt is positively and significantly related with unemployment over both the long-run and short-run, even though the value of the coefficient estimates varies amongst the sample groups. Notably, Simeon and Alexandrakis (2015) as well as Dias (2017) recently found similar findings for Euro countries and attribute this observation to the fact that increased government debt chokes up the use of government resources in debt financing which makes it difficult to increase government investment funded projects aimed at job creation. Secondly, we observed a negative and statistically significant long-run relationship between income taxes and unemployment across all sample groups, albeit this significant relationship existing for total and male unemployment rates over the short-run. This result is not surprising since higher tax revenues collected by the government would strengthen their ability to provide jobs for the unemployed. For instance, Goerke (1997) and Bohringer, Boeters, Feil (2005) find that by endogenising labour supply and the number of firms in efficiency wage models, an increase in labour income taxes will lead to lower unemployment rates. Lastly, government spending produces insignificant short-run and long-run estimates across the four unemployment groups and this finding undermines the government's ability to reduce unemployment rates through expenditure programmes. Notably our findings are in alignment with those obtained in Abrams (1999) and Mahdavi and Alanis (2013) but differ from Feldman (2006) and Linnemann (2010) who found that government size reduces unemployment in Eurozone countries.

However, as can be observed from the results of bounds test for cointegration reported in panel B of Table 2, only the two regressions associated with total and male unemployment produces an F-statistic which exceeds their upper 10\% and 5\% critical levels, respectively. On the other hand, the F-statistic associated with the 'females' and 'youth' unemployment regression lies between the lower and upper 10\% critical levels, hence rendering the reported results inconclusive. Pesaran et al. (2001) suggest that given such circumstances, in which the obtained F-statistics lies between the lower and upper critical values, one should determine the cointegration rank of the 'system' using other cointegration methods. However, since the time series were previously found to not be integrated of a similar order I(1), we are unable to determine the cointegration rank using conventional methods, such as Johansen's (2001) VECM's Eigen and Trace tests. 
Table 2. ARDL estimates of fiscal determinants of unemployment

\begin{tabular}{|c|c|c|c|c|}
\hline & $\begin{array}{c}\mathrm{U}_{\text {TOTAL }}=\mathrm{f} \\
(\mathrm{DEBT}, \mathrm{TAX}, \mathrm{EXP})\end{array}$ & $\begin{array}{c}\mathrm{U}_{\mathrm{FEMALE}}=\mathrm{f} \\
(\mathrm{DEBT}, \mathrm{TAX}, \mathrm{EXP})\end{array}$ & $\begin{array}{c}\mathrm{U}_{\mathrm{MALE}}=\mathrm{f} \\
(\mathrm{DEBT}, \mathrm{TAX}, \mathrm{EXP})\end{array}$ & $\begin{array}{c}\mathrm{U}_{\text {YOUTH }}=\mathrm{f} \\
(\mathrm{DEBT}, \mathrm{TAX}, \mathrm{EXP})\end{array}$ \\
\hline \multicolumn{5}{|c|}{ Panel A: Long-run estimates } \\
\hline DEBT & $\begin{array}{l}0.139^{* * *} \\
(0.000)\end{array}$ & $\begin{array}{l}0.130^{* * *} \\
(0.000)\end{array}$ & $\begin{array}{l}0.143^{* * *} \\
(0.000)\end{array}$ & $\begin{array}{l}0.181^{* *} \\
(0.011)\end{array}$ \\
\hline TAX & $\begin{array}{l}-0.070^{* * *} \\
(0.001)\end{array}$ & $\begin{array}{c}-0.039^{*} \\
(0.064)\end{array}$ & $\begin{array}{l}-0.091 * * * \\
(0.004)\end{array}$ & $\begin{array}{l}-0.125^{*} \\
(0.051)\end{array}$ \\
\hline EXP & $\begin{array}{l}-0.016 \\
(0.648)\end{array}$ & $\begin{array}{l}-0.005 \\
(0.912)\end{array}$ & $\begin{array}{l}-0.030 \\
(0.429)\end{array}$ & $\begin{array}{l}0.04 \\
(0.735)\end{array}$ \\
\hline \multicolumn{5}{|c|}{ Panel B: Short-run estimates } \\
\hline$\triangle \mathrm{DEBT}$ & $\begin{array}{l}0.058^{* * *} \\
(0.004)\end{array}$ & $\begin{array}{l}0.062 * * * \\
(0.004)\end{array}$ & $\begin{array}{l}0.062^{* * *} \\
(0.004)\end{array}$ & $\begin{array}{l}0.032^{* *} \\
(0.026)\end{array}$ \\
\hline$\triangle \mathrm{TAX}$ & $\begin{array}{l}-0.029 * * \\
(0.017)\end{array}$ & $\begin{array}{l}-0.018 \\
(0.214)\end{array}$ & $\begin{array}{l}-0.040^{* * *} \\
(0.006)\end{array}$ & $\begin{array}{l}-0.048 \\
(0.147)\end{array}$ \\
\hline$\Delta \mathrm{EXP}$ & $\begin{array}{l}-0.007 \\
(0.730)\end{array}$ & $\begin{array}{l}-0.002 \\
(0.924)\end{array}$ & $\begin{array}{l}-0.013 \\
(0.543)\end{array}$ & $\begin{array}{c}0.041 \\
(0.201)\end{array}$ \\
\hline \multicolumn{5}{|c|}{ Panel C: Cointegration and diagnostic tests } \\
\hline F-statistics & $3.40^{*}$ & 3.05 & $3.76^{* *}$ & 2.44 \\
\hline t-test & $-0.419 * * *$ & $-0.473 * * *$ & $-0.436^{* * *}$ & $-0.37 * * *$ \\
\hline JB test & 3.264 & 3.873 & 1.274 & 0.424 \\
\hline LM test & 6.708 & 9.237 & 5.926 & 0.802 \\
\hline $\mathrm{ARCH}$ test & 0.129 & 0.630 & 0.002 & 1.454 \\
\hline RESET Test & 0.004 & 0.011 & 0.009 & 0.631 \\
\hline
\end{tabular}

Notes: ${ }^{* * *}, * * *$ denote the $1 \%, 5 \%$ and $10 \%$ significance levels respectively. Optimal lag length selected via the Schwartz information criterion.

Source: own elaboration.

\subsection{Monetary variables as determinants of unemployment}

Having established evidence of fiscal variables such as government debt and income tax being significant short-run and long-run determinants of unemployment, we continued our analysis by investigating possible monetary determinants of unemployment for males, females and total populations. Table 3 presents the short-run and long-run ARDL estimates for the repo rate, inflation and exchange rates as possible determinants of unemployment. We observed insignificant short-run and long-run estimates for both inflation and exchange rate variables across all unemployment classifications as well as for the repo rate estimates on total and female unemployment. Note that the findings of an insignificant relationship between inflation and unemployment has been previously established for South African data (Fedderke, Schaling, 2005; Burger, Marnikov, 2006; Phiri, 2016) albeit these previous studies were only focusing on aggregated unemployment rates. However, the findings of an insignificant relationship 
between exchange rates and unemployment is contrary to previous South African literature (Chipeta, Meyer, Muzindutsi, 2017; Mpofu, Nikolaidou, 2018) which hypothesizes on currency appreciations resulting in improved job creation.

Table 3. ARDL estimates of monetary determinants of unemployment

\begin{tabular}{|c|c|c|c|c|}
\hline & $\begin{array}{c}\mathrm{U}_{\mathrm{TOTAL}}=\mathrm{f} \\
(\mathrm{REPO}, \mathrm{INF}, \mathrm{EXC})\end{array}$ & $\begin{array}{c}\mathrm{U}_{\mathrm{MALE}}=\mathrm{f} \\
(\mathrm{REPO}, \mathrm{INF}, \mathrm{EXC})\end{array}$ & $\begin{array}{c}\mathrm{U}_{\mathrm{FEMALE}}=\mathrm{f} \\
(\mathrm{REPO}, \mathrm{INF}, \mathrm{EXC})\end{array}$ & $\begin{array}{c}\mathrm{U}_{\text {YOUTH }}=\mathrm{f} \\
(\mathrm{REPO}, \mathrm{INF}, \mathrm{EXC})\end{array}$ \\
\hline \multicolumn{5}{|c|}{ Panel A: Long-run estimates } \\
\hline $\mathrm{EXC}$ & $\begin{array}{l}-0.236 \\
(0.453)\end{array}$ & $\begin{array}{l}-0.152 \\
(0.551)\end{array}$ & $\begin{array}{c}0.041 \\
(0.887)\end{array}$ & $\begin{array}{c}0.005 \\
(0.945)\end{array}$ \\
\hline INF & $\begin{array}{c}0.071 \\
(0.658)\end{array}$ & $\begin{array}{l}-0.004 \\
(0.972)\end{array}$ & $\begin{array}{l}-0.124 \\
(0.312)\end{array}$ & $\begin{array}{c}0.258 \\
(0.308)\end{array}$ \\
\hline REPO & $\begin{array}{l}-0.211 \\
(0.598)\end{array}$ & $\begin{array}{l}-0.315 \\
(0.406)\end{array}$ & $\begin{array}{l}1.573 * * \\
(0.050)\end{array}$ & $\begin{array}{c}0.655^{*} \\
(0.052)\end{array}$ \\
\hline \multicolumn{5}{|c|}{ Panel B: Short-run estimates } \\
\hline$\Delta \mathrm{EXC}$ & $\begin{array}{l}-0.025 \\
(0.471)\end{array}$ & $\begin{array}{l}-0.023 \\
(0.590)\end{array}$ & $\begin{array}{c}0.007 \\
(0.885)\end{array}$ & $\begin{array}{l}-0.018 \\
(0.412)\end{array}$ \\
\hline$\Delta \mathrm{INF}$ & $\begin{array}{c}0.008 \\
(0.546)\end{array}$ & $\begin{array}{l}-0.016 \\
(0.970)\end{array}$ & $\begin{array}{l}-0.021 \\
(0.176)\end{array}$ & $\begin{array}{c}0.101 * \\
(0.093) \\
\end{array}$ \\
\hline$\triangle \mathrm{REPO}$ & $\begin{array}{l}-0.022 \\
(0.683)\end{array}$ & $\begin{array}{l}-0.048 \\
(0.459)\end{array}$ & $\begin{array}{l}0.617 * * \\
(0.061)\end{array}$ & $\begin{array}{l}-0.436 \\
(0.349)\end{array}$ \\
\hline \multicolumn{5}{|c|}{ Panel C: Cointegration tests } \\
\hline F-statistics & 0.857 & 0.80 & $4.13 * * *$ & 1.907 \\
\hline t-test & $-0.106 * *$ & $-0.153 * *$ & $-0.172 * * *$ & $-0.247 * * *$ \\
\hline $\begin{array}{l}\text { JB tests } \\
\text { LM test }\end{array}$ & $\begin{array}{l}0.437 \\
4.157 \\
\end{array}$ & $\begin{array}{l}1.317 \\
9.438\end{array}$ & $\begin{array}{l}0.788 \\
9.521 \\
\end{array}$ & $\begin{array}{l}0.117 \\
0.636\end{array}$ \\
\hline $\mathrm{ARCH}$ test & 0.200 & 0.092 & 3.994 & 1.942 \\
\hline RESET Test & 0.094 & 0.169 & 0.001 & 0.359 \\
\hline
\end{tabular}

Notes: “***”, “***”, “*” denote the $1 \%, 5 \%$ and $10 \%$ significance levels respectively. Optimal lag length selected via the Schwartz information criterion.

Source: own elaboration.

The only exception to the reported findings are the positive and statistically significant short-run and long-run estimates on the repo rate variable for male unemployment as well as for youth unemployment, although for the latter the significance of the estimates is restricted to the long-run and does not hold over the short-run. These latter findings are reminiscent of the interest rate monetary transmission mechanism described in Mishkin (1995) and Ireland (2005) which assumes that contractionary (expansionary) monetary policy will aggravate (improve) unemployment in the economy. However, the significance of these findings is only relevant for the 'male' unemployment regression, since it produces an associated F-statistic which exceeds the upper 5\% bounds critical level. Altogether, our results imply that it is not 
the inflation outcome of monetary policy which determines unemployment but rather the manipulated monetary policy instrument which influences unemployment, at least for the South African male population. Moreover, exchange rates are found to be insignificant determinants of unemployment over both the short-run and the long-run, a result which particularly justifies the adoption of a flexible exchange rate system in which the government does not interfere with currency determination in the foreign exchange markets.

\subsection{Macroeconomic variables as determinants of unemployment}

Having examined our possible monetary and fiscal determinants of unemployment, we now estimate ARDL regressions for the macroeconomic determinants of unemployment namely, GDP, trade, domestic investment, household debt and savings. Three main empirical findings can be extracted from the results reported in Table 4. Firstly, we found the expected negative and significant long-run as well as insignificant short-run estimates on the GDP variable for all four classes of unemployment. Clearly this finding corresponds to Okun's law which previous empirical supporting evidence for this relationship has been provided by Geldenhuys and Marnikov (2007) and Phiri (2014) but differs from the findings obtained in Moroke et al. (2014) and Banda et al. (2016).

Secondly, trade, investment and household debt produce negative coefficient estimates in both the long-run and short-run equilibrium, a finding which concurs with those previously obtained in the studies of Felbermayr et al. (2011) and Guerrazzi (2015) for the tradeunemployment and investment-unemployment relationship, respectively, and yet differs from the negative household debt- unemployment relationship established in Turinetti and Zhuang (2011), Bethune, Rocheteau, and Rupert (2015) and Shaffer and Zuniga (2016). However, the significance of these estimates varies across four sample groups. For instance, the coefficient estimates on the household debt variables are statistically significant at all critical values for all unemployment categories over both the long-run and short-run. Conversely, trade produces statistically significant estimates for only male unemployment over both the long-run and shortrun whereas investment is statistically significant for total unemployment in the long-run as well as for total and male unemployment over the short-run. Moreover, the investment variable produces significant estimates for total and youth unemployment rates exclusively.

Lastly, we observed positive on the savings variable albeit only statistically significant for female and youth unemployment over both the long-run and short-run. For female unemployment, we find a positive relationship, which according to Bande-Ramudo et al. (2014) is principally correct since an increase in savings should cause the unemployment rate to 
increase due to a fall in consumption especially if the savings are precautionary and society has limited access to credit facilities. On the other hand, we found a negative relationship between savings and youth unemployment which is in line with the earlier theoretical insinuations proposed by Ioannides (1981) who hypothesizes on savings being an important determinant of unemployment, if savings are effectively directed towards productive investments which stimulate aggregate demand. Altogether we can interpret our regressions reported in Table 4 with a fair amount of confidence seeing that all regression produces F-statistics which exceed their respective 5 percent upper bounds critical levels.

Table 4. ARDL estimates of macroeconomic determinants of unemployment

\begin{tabular}{|c|c|c|c|c|}
\hline & $\begin{array}{c}\mathrm{U}_{\text {TOTAL }}=\mathrm{f} \\
(\mathrm{GDP}, \mathrm{TRADE}, \mathrm{INV}, \\
\text { HHDEBT, SAV) }\end{array}$ & $\begin{array}{c}\mathrm{U}_{\mathrm{FEMALE}}=\mathrm{f} \\
(\mathrm{GDP}, \mathrm{TRADE}, \mathrm{INV}, \\
\text { HHDEBT, SAV) }\end{array}$ & $\begin{array}{c}\mathrm{U}_{\mathrm{MALE}}=\mathrm{f} \\
(\mathrm{GDP}, \mathrm{TRADE}, \mathrm{INV} \\
\text { HHDEBT, SAV) }\end{array}$ & $\begin{array}{c}\mathrm{U}_{\text {YOUTH }}=\mathrm{f} \\
(\mathrm{GDP}, \mathrm{TRADE}, \mathrm{INV}, \\
\text { HHDEBT, SAV) }\end{array}$ \\
\hline \multicolumn{5}{|c|}{ Panel A: Long-run estimates } \\
\hline GDP & $\begin{array}{l}-0.061 * * \\
(0.070)\end{array}$ & $\begin{array}{l}-0.081 * * * \\
(0.023)\end{array}$ & $\begin{array}{c}-0.095^{*} \\
(0.092)\end{array}$ & $\begin{array}{c}-0.307^{* *} \\
(0.014)\end{array}$ \\
\hline TRADE & $\begin{array}{c}-0.002 \\
(0.632)\end{array}$ & $\begin{array}{c}-0.001 \\
(0.761)\end{array}$ & $\begin{array}{l}-0.080 * * * \\
(0.003)\end{array}$ & $\begin{array}{c}0.037 \\
(0.155)\end{array}$ \\
\hline INV & $\begin{array}{l}-0.201 * * * \\
(0.008)\end{array}$ & $\begin{array}{c}-0.072 \\
(0.230)\end{array}$ & $\begin{array}{c}-0.280 \\
(0.130)\end{array}$ & $\begin{array}{l}-0.891 * * * \\
(0.000)\end{array}$ \\
\hline HHDEBT & $\begin{array}{l}-0.277 * * * \\
(0.000)\end{array}$ & $\begin{array}{l}-0.288 * * * \\
(0.000)\end{array}$ & $\begin{array}{l}-0.266^{* * *} \\
(0.000)\end{array}$ & $\begin{array}{c}-0.066^{*} \\
(0.057)\end{array}$ \\
\hline SAV & $\begin{array}{c}0.102 \\
(0.107) \\
\end{array}$ & $\begin{array}{l}0.145^{* *} \\
(0.043)\end{array}$ & $\begin{array}{c}0.033 \\
(0.722) \\
\end{array}$ & $\begin{array}{c}-0.399 * \\
(0.075)\end{array}$ \\
\hline \multicolumn{5}{|c|}{ Panel B: Short-run estimates } \\
\hline$\Delta \mathrm{GDP}$ & $\begin{array}{c}-0.056 \\
(0.161)\end{array}$ & $\begin{array}{c}-0.074 \\
(0.120)\end{array}$ & $\begin{array}{c}-0.057 \\
(0.217)\end{array}$ & $\begin{array}{c}-0.088 \\
(0.224)\end{array}$ \\
\hline$\triangle \mathrm{TRADE}$ & $\begin{array}{c}-0.002 \\
(0.757)\end{array}$ & $\begin{array}{c}-0.001 \\
(0.875)\end{array}$ & $\begin{array}{l}-0.048 * * * \\
(0.002)\end{array}$ & $\begin{array}{c}0.009 \\
(0.379) \\
\end{array}$ \\
\hline$\Delta \mathrm{INV}$ & $\begin{array}{l}-0.183 * * * \\
(0.018)\end{array}$ & $\begin{array}{c}-0.066 \\
(0.406) \\
\end{array}$ & $\begin{array}{c}-0.168^{* *} \\
(0.070)\end{array}$ & $\begin{array}{l}-0.732 * * * \\
(0.007)\end{array}$ \\
\hline$\triangle \mathrm{HHDEBT}$ & $\begin{array}{l}-0.253 * * * \\
(0.000)\end{array}$ & $\begin{array}{l}-0.264 * * * \\
(0.000)\end{array}$ & $\begin{array}{l}-0.160 * * * \\
(0.001)\end{array}$ & $\begin{array}{c}-0.168 * * \\
(0.029)\end{array}$ \\
\hline$\Delta \mathrm{SAV}$ & $\begin{array}{c}0.093 \\
(0.122)\end{array}$ & $\begin{array}{c}0.133^{*} \\
(0.072)\end{array}$ & $\begin{array}{c}0.020 \\
(0.733)\end{array}$ & $\begin{array}{c}-0.196 \\
(0.275)\end{array}$ \\
\hline \multicolumn{5}{|c|}{ Panel C: Cointegration and diagnostic tests } \\
\hline F-statistics & $4.70 * * *$ & $5.55^{* * *}$ & $6.37 * * *$ & $8.151^{* * *}$ \\
\hline $\begin{array}{l}\text { t-test } \\
\text { JB tests }\end{array}$ & $\begin{array}{c}-0.913 * * * \\
1.141\end{array}$ & $\begin{array}{c}-0.918^{* * *} \\
0.853\end{array}$ & $\begin{array}{l}-0.600 * * * \\
1.595\end{array}$ & $\begin{array}{l}-0.524 * * * \\
0.162 \\
\end{array}$ \\
\hline LM test & 12.217 & 0.744 & 1.196 & 0.175 \\
\hline ARCH test & 0.253 & 0.261 & 0.097 & 0.984 \\
\hline RESET test & 0.492 & 1.876 & 1.116 & 1.272 \\
\hline
\end{tabular}

Notes: $* * *, * * *$ denote the $1 \%, 5 \%$ and $10 \%$ significance levels respectively. Optimal lag length selected via the Schwartz information criterion.

Source: own elaboration. 


\section{Conclusions}

Concerned by the outlook of unemployment in South Africa following the advent of the 2007-2008 global financial crisis, our study sought to examine certain monetary, fiscal and macroeconomic determinants of unemployment exclusively focusing on the post-crisis era. Our selection of variables as possible determinants of unemployment in our study is primarily guided by theoretical intuition based upon the existing academic literature in conjunction with the availability of time series data from various sources. To ensure we obtained a sufficient number of observations which are sufficient for empirical analysis we restricted our variables to a time series which are available in quarterly frequencies covering a period of 2008:q1 to 2018:q4. Our empirical regressions were estimated using the ARDL framework of Pesaran et al. (2001) and there are three broad findings which we highlight from our empirical findings. Firstly, government debt and income taxation are important fiscal determinants of unemployment in the post-recession period. Secondly, the repo rate is the only significant monetary determinant of unemployment found in the post-recession era. Lastly, economic growth, trade, domestic investment household debt and to a lesser extent savings rate are important macroeconomic determinants of unemployment in the post-crisis period.

In further disseminating our results from a policy perspective, we observed that variables such as income taxes, economic growth, domestic investments, and to a lesser extent trade (for male unemployment) and saving (for female and youth unemployment) all need to be stimulated by policymakers in order to reduce unemployment. On the other hand, fiscal variables such as government debt and the Reserve Bank's short-term policy instrument need to be suppressed. This later finding implies the need for fiscal policy to increase income taxes yet simultaneously reduce government debt. We, however, note the insignificant effects of government spending on both short-run and long-run unemployment, which reflects the inadequacy of recently implemented fiscal expenditure projects in solely attempting to eradicate unemployment in the country. From a monetary policy standpoint, our results indicate that the Reserve Bank needs to relax their hikes on interest rates in the interest of stimulating the economy and consequentially reducing steady-state unemployment. Moreover, the observed insignificant effect of inflation on unemployment further questions the usefulness of an inflation-targeting regime in addressing the issue of unemployment via price stability.

From the perspective of the different categories of unemployment, we observed that monetary-fiscal-macroeconomic coordination would only be beneficial to the male population seeing that this is the only category of unemployment that is responsive to monetary policy 
and fiscal instruments in the post-crisis era. We noted that female and youth unemployment classifications are not significantly responsive to monetary and fiscal variables but are instead mutually responsive to output growth, household debt and savings whilst youth unemployment is solely responsive to domestic investments. Interestingly, GDP growth, household debt, savings and domestic capital accumulation have been on a declining trend in the post-crisis periods, and based on our empirical findings, this will not beneficial to either female or youth unemployment. On the other hand, only the trade balance has improved in recent times and yet based on our empirical analysis, we found that only the male population gains from the associated trade benefits. Overall, our study shows a bias in the implementation of monetaryfiscal policy coordination efforts and trade policies towards improving male unemployment rates and urges policymakers to consider devising policies particularly focused on addressing female and youth unemployment.

\section{References}

Abrams, B. (1999). The effect of government size on the unemployment rate. Public Choice, 99 (3/4), 395-401. DOI: 10.1023/A:1018349411246.

Banda, H., Ngirande, H., Hogwe, F. (2016). The impact of economic growth on unemployment in South Africa: 1994-2012. Investment Management and Financial Innovation, 13 (2), 246-255. DOI: 10.21511/imfi.13(2-1).2016.11.

Bande-Ramudo, R., Fernandez-Grela, M., Riveiro-Garcia D. (2014). Consumption, investment and unemployment: SVAR tests of the effects of changes in the consumption-saving pattern. Cogent Economics and Finance, 2 (1), 1-7. DOI: 10.1080/23322039.2014.933676.

Banerjee, A., Dolado, J., Mestre, R. (1998). Error-correction mechanism tests for cointegration in single-equation framework. Journal of Time Series Analysis, 19 (3), 267-283. DOI: 10.1111/1467-9892.00091.

Berger, T., Everaert, G. (2010). Labour taxes and unemployment evidence from a panel unobserved component model. Journal of Economic Dynamics and Control, 34 (3), 354-364. DOI: 10.1016/j.jedc.2009.09.010.

Bethune, Z., Rocheteau, G., Rupert, P. (2015). Aggregate unemployment and household unsecured debt. Review of Economic Dynamics, 18 (1), 77-100. DOI: 10.1016/j.red. 2014.08.002.

Blanchard O., Wolfers, J. (2000). The role of shocks and institutions in the rise of European unemployment. The Economic Journal, 110 (462), 1-33. DOI: 10.1111/1468-0297.00518. 
Bohringer, C., Boeters, S., Feil, M. (2005). Taxation and unemployment: an applied general equilibrium approach. Economic Modelling, 22 (1), 81-108. DOI: 10.1016/j.econmod.2004.05.002.

Burger, P., Marnikov, M. (2006). The South African Phillips curve: How applicable is the Gordon model? South African Journal of Economics, 74 (2), 172-189. DOI: 10.1111/j.18136982.2006.00062.x.

Chipeta, C., Meyer, F., Muzindutsi, P. (2017). The effect of exchange rates movements and economic growth on job creation. Studia Universitatis Babes-Bolyai Oeconomica, 62 (2), 20-41. DOI: 10.1515/subboec-2017-0007.

Dagume, M., Gyekye, A. (2016). Determinants of youth unemployment in South Africa: Evidence from the Vhembe district of Limpopo province. Environmental Economics, 7 (4), 59-67. DOI: 10.21511/ee.07(4).2016.06.

de Mendonca, H., de Oliveira, D. (2019). Firms' confidence and Okun's law in OECD countries. Economic Modelling, 78 (C), 98-107. DOI: 10.1016/j.econmod.2018.08.015.

Dias, J. (2017). Unemployment and sovereign debt crisis in the Eurozone: A k-means-r analysis. Physica A: Statistical Mechanics and its Applications, 482 (15), 108-117. DOI: 10.1016/j.physa.2017.04.022.

Du Toit, M., De Witte, H., Rothman, S., Van den, Broeck A. (2018). Contextual factors and the experience of unemployment: A review of qualitative studies. South African Journal of Economic and Management Sciences, 21 (1), 1-11. DOI: 10.4102/sajems.v21i1.2083.

Driver, C., Munoz-Bugarin, J. (2010). Capital investment and unemployment in Europe: Neutrality or not? Journal of Macroeconomics, 32 (1), 492-496. DOI: 10.1016/j.jmacro.2009.03.003.

Dutt, P., Mitra, D., Ranjan, P. (2009). International trade and unemployment: Theory and crossnational evidence. Journal of International Economics, 78 (1), 32-44. DOI: 10.1016/j. jinteco.2009.02.005.

Egger, H., Kreickemeier, U. (2009). Firm heterogeneity and the labour market effects of trade liberalization. International Economic Review, 50 (1), 187-216. DOI: 10.1142/97898 13224919_0010.

Fedderke, J., Schaling, E. (2005). Modelling inflation in South Africa: A multivariate cointegration analysis. South African Journal of Economics, 73 (1), 79-92. DOI: 10.1111/j.18136982.2005.00006.x.

Felbermayr, G., Schmerer, H., Prat, J. (2011). Trade and unemployment what do the data say. European Economic Review, 55 (6), 741-758. DOI: 10.1016/j.euroecorev.2011.02.003.

Feldman, H. (2006). Government size and unemployment: Evidence from industrial countries. Public Choice, 127 (3/4), 451-467. DOI: 10.1007/s11127-005-9003-y. 
Fuhrer, J. (1995). The Phillips curve is alive and well. New England Economic Review. March Issue, 41-56.

Geldenhuys, J., Marnikov, M. (2007). Cyclical unemployment and cyclical output: An estimation of Okun es coefficient for South Africa. South African Journal of Economics, 75 (3), 373-390. DOI: 10.1111/j.1813-6982.2007.00134.x.

Goerke, L. (1997). Taxes in an efficiency wage economy in the short-run and in the long-run. Public Finance Analysis, 54 (4), 447-470. https://www.jstor.org/stable/40912792.

Gordon, R. (1990). The Phillips curve now and then. NBER Working Paper No. 3393, June.

Grant, A. (2018). The recession and Okun's law. Economic Modelling, 69 (C), 291-300. DOI: 10.1016/j.econmod.2017.10.002.

Guerrazzi, M. (2015). Animal spirits, investment and unemployment: An old Keynesian view of the Great Recession. Economia, 16 (3), 343-358. DOI: 10.1016/j.econ.2015.09.002.

Guisinger, A., Hernandez-Murillo, R., Owyang, M., Sinclair, T. (2018). A state-level analysis of Okun's law. Regional Science and Urban Economics, 68 (C), 239-248. DOI: 10.1016/j. regsciurbeco.2017.11.005.

Hasan, R., Mitra, D., Ranjan, P., Ahsan, R. (2012). Trade liberalization and unemployment: Theory and evidence from India. Journal of Development Economics, 97 (2), 269-280. DOI: 10.1016/j.jdeveco.2011.04.002.

Ioannides, Y. (1981). Job search, unemployment and savings. Journal of Monetary Economics, 7 (3), 355-370. DOI: 10.1016/0304-3932(81)90034-9.

Ireland, P. (2005). The monetary transmission mechanism. Federal Reserve Bank of Boston Working Paper No. 06-1, November.

Karafolas, S., Alexandrakis, A. (2015). Unemployment effects of the Greek crisis: A regional examination. Procedia Economics and Finance, 19, 82-90. DOI: 10.1016/S22125671(15)00010-6.

Kingdon, G., Knight, J. (2007). Unemployment in South Africa: Causes, problems and policies. Journal of African Economies, 16 (5), 813-848. DOI: 10.1080/03768358408439101.

Kyei, K., Gyekye, K. (2012). Unemployment in Limpopo province in South Africa: Searching for factors. Journal of Social Sciences, 31 (2), 177-185. DOI: 10.1080/09718923.2012.11893026.

Latif, A. (1996). Can an increase in national savings reduce the level of unemployment in Australia? Applied Economics Letters, 3 (5), 329-332. DOI: 10.1080/135048596356456.

Linnemann, L. (2010). Unemployment, government spending and the Laffer effect. Fiscal Studies, 31 (2), 227-250. DOI: 10.1111/j.1475-5890.2010.00113.x.

Malley, J., Moutos, T. (2001). Capital accumulation and unemployment: A tale of two 'continents'. The Scandinavian Journal of Economics, 103 (1), 79-99. DOI: 10.1111/14679442.00231. 
Mahdavi, S., Alanis, E. (2013). Public expenditures and the unemployment rate in the American states: Panel evidence. Applied Economics, 45 (20), 2926-2937. DOI: 10.1080/00036846. 2012.690849.

Mishkin, F. (1995). Symposium on the monetary transmission mechanism. Journal of Economic Perspectives, 9 (4), 3-10. DOI: 10.1257/jep.9.4.3.

Moroke, N., Leballo, G., Mello, D. (2014). An empirical robustness of Okun's law in South Africa: An error correction modelling approach. Mediterranean Journal of Social Sciences, 5 (23), 435-443. DOI: 10.5901/mjss.2014.v5n23p435.

Mlatsheni, C., Leibbrandt, M. (2011). Youth unemployment in South Africa: Challenges, concepts and opportunities. Journal of International Relations and Development, 14 (1), 118 126. DOI: $10.1057 /$ jird.2010.24.

Mpofu, T., Nikolaidou, E. (2018). Real exchange rate volatility and employment growth in South Africa: The case of manufacturing. ERSA Working Paper No. 737, March.

Naude, W., Serumaga-Zake, P. (2001). An analysis of the determinants of labour force participation and unemployment in South Africa's North-West province. Development Southern Africa, 18 (5), 261-278. DOI: 10.1080/03768350120041929.

Nickell, S., Nunziata, L., Ochel, W. (2005). Unemployment in OECD since the 1960's. What do we know?. The Economic Journal, 115 (500), 1-27. Retrieved from: https://www.jstor. org/stable/3590502.

Okun, A. (1962). Potential GNP: Its measurement and its significance. American Statistical Association, Proceedings of the Business and Economics Section, 98-103.

Patel, D., Choga, I. (2018). Determinants of youth unemployment in South Africa. Proceedings of Economics and Finance Conferences, 7108913, International Institute of Social and Economic Sciences.

Pesaran, H., Shin, Y., Smith, R. (2001). Bounds testing approaches to the analysis of level relationships. Journal of Applied Econometrics, 16 (3), 289-326. DOI: 10.1002/jae.616.

Phiri, A. (2014). Nonlinear co-integration between unemployment and economic growth in South Africa. Managing Global Transitions, 12 (2), 81-102.

Phiri, A. (2016). Examining asymmetric effects in the South African Phillips curve: Evidence from logistic smooth transition regression models. International Journal of Sustainable Economy, 8 (1), 18-42. DOI: 10.1504/IJSE.2016.073683.

Planas, C., Roeger, W., Rossi, A. (2007). How much has labour taxation contributed to European structural unemployment? Journal of Economic Dynamics and Control, 31 (4), 1359-1375. DOI: 10.1016/j.jedc.2006.05.005.

Porras-Arena, S., Martin-Roman, A. (2019). Self-employment and Okun's law. Economic Modelling, 77 (C), 253-265. DOI: 10.1016/j.econmod.2018.09.006. 
Shaffer, S., Zuniga, B. (2016). Consumer debt and unemployment. Applied Economic Letters, 23 (17), 1250-1252. DOI: 10.1080/13504851.2016.1148250.

Turinetti, E., Zhuang, H. (2011). Exploring determinants of U.S. debt. Journal of Applied Business Research, 27 (6), 85-92. DOI: 10.19030/jabr.v27i6.6468. 